\title{
Internet Lending and Small and Medium-Sized Enterprises Financing
}

\author{
Cen Yu \\ Ningbo Dahongying University, Ningbo, Zhejiang, China \\ 314720157@qq.com
}

Key words: Internet, Lending, Small and Medium-sized enterprises financing

Abstract: Internet finance is a financial innovation spawned out under the background of the financing difficulties of small and medium-sized enterprises. In numerous internet financial models, the most closely model to small and medium-sized enterprises financing is internet lending. The paper, through the analysis of the model and the advantages of internet lending, provides reasonable suggestions for small and medium-sized enterprises using internet platform for financing.

\section{Introduction}

Internet lending means the supplier and demand of the funds, both sides to conduct funds lending "online transactions" through the network platform. By using the internet, big data and other new technologies, the internet platform will conduct information matching and tool support, and ultimately achieve a low cost and transparent small loan.

\section{Main Model of Internet Lending}

Benefit from the application of mass data as well as the innovative technology and business model, the internet lending business has developed rapidly in the world. In recent years, China' $\mathrm{s}$ internet lending industry also showed explosive growth. Since it occurred in 2006 to present, China has more than 2000 network lending platforms. At present, the mode of the platform is different, and summed up mainly have the following three categories:

\subsection{The transaction model guaranteed by guarantee institutions.}

Such platform will act as an intermediary; the platform no savings-absorbing and no lending, it only provides financial information services; the cooperated small loan companies and guarantee agencies provide a double guarantee, and this is the most safety P2P model.

\subsection{Creditor's right contract transferring model.}

The borrowing demand and investment under the model are scattered combination, as the largest creditors to lend funds to borrowers, obtain the creditor's rights and then segmentation, through the way of transferring of creditor's right to other investors, and then obtain the lending fund.

\subsection{The internet service platform launched by a large financial group.}

This platform has a large group background, and is made up of the traditional financial industry to the internet layout, therefore, it is more professional in its product and service providing.

\section{The Advantages of Intern Lending in Small and Medium-sized Enterprises Financing}

\subsection{The threshold of internet lending is low, and customer base is wide}

According to "Eighty-Twenty Rule” , 20\% customers can produce 80\% efficiency. The traditional financing institution due to high cost and other reasons, the main service target is $20 \%$ of the big customers. But the internet finance more towards the $80 \%$ of "long-tail” customers. This small customer's financial needs are small and personalized; it is difficult to satisfy in the traditional financial system. but by internet lending platform, as long as there is fund demand, the demander can publish his/her borrowing information on the website, which is greatly expand the customer 
grouped participating in online lending.

\subsection{Internet Lending is Fast, and Procedure is Simple}

The traditional financial institutions need to operate according to the traditional loan formalities, the whole process lead to long lending circle, and it is difficult to solve the capital demander' s immediate needs. In contrast, the internet lending formalities is simple and convenience; it does not need a low of procedures. The customer can directly submit his/her loan application online, and the platform will conduct loan evaluation, the loan conducting cycle can be shortened greatly. In the case of many enterprises need fund urgently, it can help enterprises to go through a difficult period.

\subsection{The interest rate of internet lending is low, and the payment way is flexible}

In traditional loan, the actual loan interest rate of the commercial bank is much higher than the benchmark interest rate. Internet lending can match the most suitable and lowest interest rate products for customers through the online platform, and as far as possible for customers to reduce the unnecessary expenses in loan links.

At the same time, in the loan issuance process, as far as possible to reduce the risk of misappropriation of loan, the loan issued by the commercial bank has more limitations; but there are no such limitations in internet platform lending; when the bidding is completed or the final evaluation by the website is qualified, the borrowed fund can flow into the borrower' s account, is more flexible.

\subsection{There is a lower risk of internet lending, and pure credit loan accounts for important position}

The internet lending platform does not assume the liability for overdue loan repayment in principle, but merely assist lenders collecting debts or impose punitive measures on defaulting borrowers, online lending platform avoid risk by this, so the requirements for the mortgage and guarantee of the borrowers while borrowing is low, many internet lending is pure credit loan. The small and medium-sized enterprises due to lack of collateral or guarantee of the third party, the dilemma of difficult to get loans from commercial bank can be eased through online lending platform.

\section{Problems that should be paid attention to by the small and medium-sized enterprises using the internet lending}

The continuous development of internet lending plays a greater role in effective relief of the financing difficulties of the small and medium-sized enterprises; meanwhile, it has brought a multi-win-win for the capital supply and demand sides and the lending platform. But at present, the internet lending has imperfect aspects such as credit assessment, business supervision, system platform, legal norms and etc., so that it faced with many difficulties in their own development and financing of the small and medium-sized enterprises. Therefore, in the use of internet lending, the small and medium-sized enterprises should pay attention to the following issues:

\subsection{To improve the information transparency of the small and medium-sized enterprises}

The small and medium-sized enterprises, when using of internet lending platform for financing, shall strengthen the disclosure of their own information. In the time of borrowing, shall public their information; during the borrowing period, shall regularly public the fund' $s$ investment and use efficiency, to make the people who provide funds can understand the credibility of the enterprise, so that the borrowing can be more effective. If the enterprise can obtain the full trust of the fund provider, they can establish long-term cooperative relations; ensure the sustainable fund chain, and as to effectively use the platform to assist the development of the small and medium-sized enterprises.

4.2 The small and medium-sized enterprises shall choose the internet lending platform for financing carefully 
The small and medium-sized enterprises shall follow the principle of caution when using the internet lending platform to borrow. Firstly, shall select the platform with stronger background shareholders, better rick-control system and higher credibility. Secondly, to strictly inspect the financing model, operating procedures, and financing cost, then choose the most suitable and lowest comprehensive cost platform, to achieve low-interest lending mode, and accelerate the development of the enterprise.

\subsection{To strengthen the supervision on internet lending platform operation}

Due to lack of supervision, internet lending has produced many problems and outbreak a lot of risks in the process of development, therefore, the government' s effective supervision and regulation on internet lending platform is imminent. The supervision authority should strictly control the source, whereabouts and amount of the funds, to manage the lending funds by third party institutions, isolate the customer' s funds and platform' s own funds, which can effectively prevent customer' s fund stolen, embezzled, or used for illegal matters.

\section{Summary}

In summary, as the necessary an effective supplement to the traditional banking system, internet lending is expected to achieve explosive growth in China, and promote the realization of Financial Inclusion in China. The financing of small and medium-sized enterprise cannot be separated from the internet finance to raise fund for enterprise development, in order to achieve the goal of sustainable development of enterprises.

\section{References:}

[1] Wang Zhenyi, Xiao Hao and He Huqin, P2P Online Lending Platform Operation Model and Risk Prevention Strategy, Journal of Wuhan Textile University, vol.01,pp.11-14,2015.

[2] Yang Xiaojuan, Analysis of P2P Online Lending Problems from the Perspective of Small and Medium-Sized Enterprises Financing, Times Finance, vol.01, pp. 103-104, 2015.

[3] Dong Manwei, Bai Yujuan, P2P Online Lending Model Development Status, Risk Analysis and Countermeasures Study, Economist, vol.04, pp.:62-63, 2015.

[4]Chen Wen, Wang Fei, Online Lending and Small and Medium-Sized Enterprises Financing, Beijing: Economy \& Management Publishing House, 2014. 